\title{
Uso de Imagem Termal do Satélite Landsat-8 para Análise das Variações de Temperaturas do Ar na Cidade de Barra do Garças, Estado de Mato Grosso
}

\author{
Use of a Thermal Image from the Landsat-8 Satellite to Analyze Air Temperature \\ Variations in the City of Barra do Garças, State of Mato Grosso
}

\begin{abstract}
El Uso de la Imagen Térmica del Satélite Landsat-8 e para el Análisis de las Variaciones de las Temperaturas del Aire en la Ciudad de Barra do Garças, Estado de Mato Grosso
\end{abstract}

\author{
Romário Rosa de Sousa ${ }^{1}$ \\ https://orcid.org/0000-0002-6875-0989 \\ Samuel do Carmo Lima² \\ https://orcid.org/0000-0002-0950-8666
}

\begin{abstract}
RESUMO: Este trabalho teve como objetivo principal analisar as variações de temperaturas do ar na cidade de Barra do Garças, a partir da utilização de imagem termal do satélite Landsat-8. Os procedimentos de aquisição das imagens orbitais digitais gratuitas foram obtidas do satélite Landsat 8 sensor OLI (Operational Land Imager) no Serviço de Levantamento Geológico Americano (USGS), considerando a órbita 224, ponto 71 , datadas de 24/06/2016 a 02/09/2018, horário central 10:30 horas, banda: 10 com resolução espacial de 30 metros e banda 10 infravermelho termal (10.6 - 11.19 um - micrômetro), com o intuito de verificar o comportamento da temperatura na área urbana do município de Barra do Garças. Os dados diários terrestres de temperatura foram adquiridos do Banco de Dados Meteorológicos para Ensino e Pesquisa BDMEP/INMET, referente à estação meteorológica de Aragarças-GO. Mediante a análise das imagens termais para o período em questão, visualizou-se que o mês de setembro registrou os maiores valores, $2017 \mathrm{com} 48^{\circ} \mathrm{C}, 2016 \mathrm{com} 44^{\circ} \mathrm{C}$ e $2018 \mathrm{com}$ $38^{\circ} \mathrm{C}$. Constatou-se, ao longo da análise efetuada, que as temperaturas mais elevadas aconteceram nos bairros que estão nos locais mais baixo do sítio urbano. Assim as porções oeste, sul e o extremo leste apresentaram temperaturas aquecidas.
\end{abstract}

PALAVRAS-CHAVE: Temperatura do ar. Imagem termal. Sensoriamento remoto.

ABSTRACT: The principal objective of this paper is to analyze the changes of air temperature in the city of Barra do Garças - MT, using the thermal images of the landsat-8 satellite. The procedures for acquiring free digital orbital images were obtained from the Landsat Satellite - 8 OLI sensor (Operational Land Imager) at the American Geological Survey Service (USGS), considering orbit 224,

1 Doutorando do Programa de Pós-Graduação em Geografia - UFU. E-mail:
romarioufg@yahoo.com.br.
${ }^{2}$ Professor Doutor do Programa de Pós-Graduação em Geografia - UFU. E-mail: samuel@ufu.br. 
point 71 , dated 06/24/2016 to 09/02/2018, central time 10:30 am, band: 10 with spatial resolution of 30 meters and thermal band 10 infrared (10.6 - $11.19 \mu \mathrm{m}$ - micrometer), in order to observe the temperature behavior in the urban area of Barra do Garças. The terrestrial daily temperature data were acquired from the Weather Database for Teaching and Research BDMEP / INMET, referring to the weather station of Aragarças - GO. From the analysis observed through thermal images for the affore mentioned period, it was seen that the month of September registered the highest values, in the year of 2017, the peak was $48^{\circ} \mathrm{C}$, in 2016 it was $44^{\circ} \mathrm{C}$ and in 2018 it was $38^{\circ} \mathrm{C}$. It was found that, throughout this analysis, the highest temperatures occurred in the neighborhoods that are in the lowest places of the urban site. Therefore, the western, southern and extreme eastern portions of the city showed higher temperatures.

KEYWORDS: Air temperature. Thermal image. Remote detection.

RESUMEN: Este trabajo tuvo como objetivo principal analizar las variaciones de las temperaturas del aire em la ciudad de Barra do Garças - MT, desde la utilización de la imagen térmica del satélite Landsat-8. Los procedimientos de la adquisición de imágenes orbitales digitales gratuitas se obtuvieron del satélite Landsat - 8 sensor OLI (Operational Land Imager) en el Servicio de Levantamineto Geological American (USGS), considerando la órbita 224, punto 71, del 24/06/2016 al 02 / 09/2018, hora central 10:30 am, banda: 10 con resolución espacial de 30 metros y banda 10 infrarroja térmica (10.6 - $11.19 \mu \mathrm{m}$ - micrómetro), para verificar el comportamiento de la temperatura en el área urbana del municipio de Barra do Garças. Los datos diarios de la temperatura terrestre se obtuvieron de la Base de datos meteorológicos para la enseñanza y la investigación BDMEP / INMET, en referencia a la estación meteorológica de Aragarças - GO. A través de las análisis observada en las imágenes térmicas para el período en cuestión, se observó que el mes de septiembre registró los valores más altos, donde 2017 con $48^{\circ} \mathrm{C}, 2016$ con $44^{\circ} \mathrm{C}$ y 2018 con $38^{\circ} \mathrm{C}$. Se encontró que en al largo del análisis realizada, las temperaturas más altas ocurrieron en los barrios que se están en los lugares más bajos del sitio urbano. Así las porciones oeste, sur y extremo oriente mostraron temperaturas cálidas.

PALABRAS CLAVE: Temperatura del aire. Imagen térmica. Detección remota.

\section{INTRODUÇÃO}

Com a expulsão do homem no campo e o desmatamento das coberturas vegetais remanescentes para maximização das pastagens, ocorre como consequência o inchaço do sítio urbano municipal. Os expropriados ocupam as adjacências da poligonal urbana, a exemplo de encostas dos vales, proximidades de córregos e rios, área de preservação permanente e reservas. Com isso sabe-se que o modelo de desenvolvimento implantado está atrelado ao aumento da produção do setor secundário e da infraestrutura necessária, não levando em consideração que a industrialização concentrada em áreas específicas do território atrai contingentes populacionais e gera um modelo de desenvolvimento desestruturado das cidades (MELO, 2016).

A cidade e suas configurações podem se encaixar na escala local e na microclimática do clima, respectivamente, diagnosticando-se as relações existentes entre os elementos da natureza e os parâmetros climáticos do clima urbano, daí a necessidade do 
desenvolvimento de pesquisas que envolvem a análise da dinâmica climática (STEINKE; STEINKE, 2014).

Os tempos que atravessamos nas cidades mostram uma sensível tendência de irregularidade no ritmo climático em função dos nossos vínculos zonais, regionais e locais a quadros climáticos intertropicais, que influenciam na distribuição das chuvas; havendo um maior prolongamento das secas e curtos períodos chuvosos, sendo que em determinados espaços de tempo pode ocorrer uma inversão, ou seja, chuva demais e seca de menos (MONTEIRO, 1971).

Segundo Mendonça (2000), as cidades de porte médio e pequeno possuem então características geográficas bastante diferenciadas daquelas de grande porte e metropolitanas e apresentam, portanto, consideráveis facilidades para a identificação de suas paisagens intra-urbanas; essas, previamente identificadas, permitirão uma melhor compreensão da interação sociedade-natureza na construção do clima urbano.

$\mathrm{Da}$ forma desordenada como se tem ocupado os espaços terrestres, estes têm se transformados em cidades, em condições diversas e sem um planejamento sério, e exercem uma influência determinante na formação de condições climáticas intra-urbanas, uma vez que o processo de calor sensível que se desenvolve intensifica o aquecimento atmosférico, sendo esse transportado pelos ventos para a cidade; ainda, a cidade estoca calor devido às diferentes propriedades dos materiais que a constituem.

De acordo com Ynoue et al. (2017), no balanço de energia global que entra e que sai da Terra, apesar do sol emitir quase constantemente a mesma quantidade de energia, observam-se variações de temperatura tanto ao longo de um dia quanto ao longo do ano.

As considerações de Ferretti (2012) sobre o colapso de sociedades inteiras não pode ser ignorado, boa parte da população mundial vive na pobreza, sem água potável, sem acesso à assistência básica da saúde, com educação e moradia inadequada, e assim visualiza-se um direcionamento governamental nas diversas esferas da administração pública voltadas apenas para o que é de interesse. Neste sentido sabe-se que questões ambientais não são bem vistas e, por outro lado, devem-se considerar as implicações no crescimento econômico das cidades.

É fato que o processo de urbanização implementado no Brasil, a partir da década de 1970, caracterizou-se pelo desordenamento, pela impermeabilização do solo e pelas alterações hidrodinâmicas dos espaços territoriais urbanos, promovendo inéditas alterações na temperatura e na pluviosidade em função dessas alterações no ambiente local (TARIFA; AZEVEDO, 2001). Desse modo, este trabalho teve como objetivo principal analisar as variações de temperaturas do ar na cidade de Barra do Garças, estado do Mato Grosso. 


\section{METODOLOGIA}

O Estado de Mato Grosso está localizado entre as coordenadas geográficas de latitudes $7^{\circ}$ a $18^{\circ}$ Sul e longitudes $50^{\circ}$ a $62^{\circ}$ Oeste de Greenwich. As altitudes variam de 100 a 1200 metros, no centro do Continente Sul Americano. Foi definido, como área de estudo, o município de Barra do Garças, localizado às margens do Rio Araguaia, no estado de Mato Grosso, na divisa com o estado de Goiás (Figura 01).

Figura 01 - Localização do município de Barra do Garças, sudeste do estado de Mato
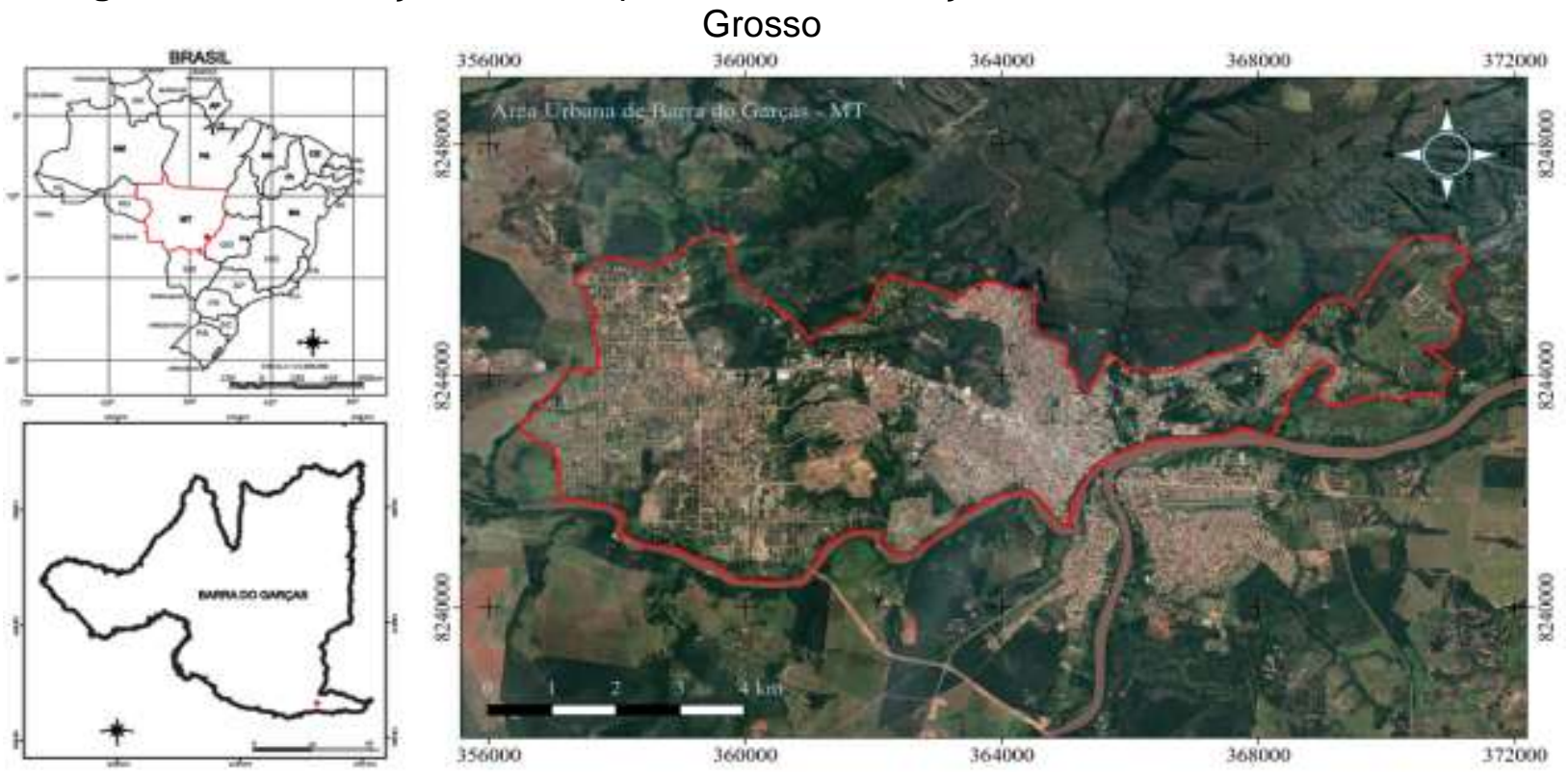

Fonte: elaborado por: R. R. de Sousa, de IBGE (2016).

Os procedimentos de aquisição das imagens orbitais digitais gratuitas foram obtidas do satélite Landsat - 8 sensor OLI (Operational Land Imager) no Serviço de Levantamento Geológico Americano (USGS), considerando a órbita 224, ponto 71, datadas de 24/06/2016 a 02/09/2018, horário central 10:30 horas, banda: 10 com resolução espacial de 30 metros e banda 10 infravermelho termal (10.6 - $11.19 \mu \mathrm{m}$ - micrômetro), com o intuito de verificar o comportamento da temperatura na área urbana do município de Barra do Garças.

As manipulações das imagens foram realizadas no software Q-GIS, versão 3.10. $\mid O$ desenvolvimento da metodologia usada para calcular a Temperatura da Superfície (TS) foi baseada no artigo de Avdan e Jovanovska (2016). A TS de uma dada imagem LANDSAT 8 é calculada a partir do uso das bandas 4 (visível; 0,64-0,67 $\mu \mathrm{m}$ ), 5 (infravermelho próximo; 0,85-0,88 $\mu \mathrm{m}$ ) e 10 (sensor infravermelho termal (TIRS); 10,6-11,19 $\mu \mathrm{m}$ ). A banda 10 foi usada para estimar a temperatura de brilho e as bandas 4 e 5 foram usadas para calcular 0 IVDN (Índice de Vegetação por Diferença Normalizada). As constantes utilizadas nesse 
algoritmo foram obtidas do arquivo de metadados que vem junto com as imagens de satélite e são mostrados no Quadro 01.

Quadro 01 - Meta dados das imagens de satélite

\begin{tabular}{|c|}
\hline Constante Térmica, Banda 10 \\
\hline $\mathrm{K}_{1}=774,8853$ \\
\hline $\mathrm{K}_{2}=1321,0789$ \\
\hline Fator de Redimensionamento, Banda 10 \\
\hline $\mathrm{M}_{\mathrm{L}}=0,0003342$ \\
\hline $\mathrm{A}_{\mathrm{L}=0,1}$
\end{tabular}

Organizado por: L. F. P. Barbieri (2019). Fonte: dados da pesquisa.

São necessários seis passos para obtermos a TS:

1 - Cálculo da Radiância Espectral do Topo da Atmosfera $(L \lambda)$ :

$L \lambda=M_{L} \times Q_{c a l}+A_{L}$

Em que:

$M_{\llcorner}$representa o fator de redimensionamento multiplicativo específico da banda;

$Q_{\text {cal }}$ é a imagem da Banda 10;

$A_{L}$ é o fator de redimensionamento aditivo específico da banda.

2 - Conversão da $L \lambda$ para a Temperatura de Brilho (BT):

$B T=\frac{K_{2}}{\ln \left[\left(\frac{K_{1}}{\mathrm{~L} \lambda}\right)+1\right]}-273,15$

Em que:

$\mathrm{K}_{1}$ e $\mathrm{K}_{2}$ representam as constantes de conversão térmica específicas da banda.

Para obter o resultado em graus Celcius, foi adicionado o zero absoluto, valor aproximado $273,15^{\circ} \mathrm{C}$, à equação da temperatura radiante.

3 - Cálculo do NDVI:

As bandas do visível (VIS) e infravermelho próximo (NIR) do Landsat foram usadas para calcular o NDVI. Esse cálculo é importante pois, em seguida, a Proporção de Vegetação $\left(P_{v}\right)$ deverá ser calculada, que está relacionada o NDVI e, posteriormente, a Emissividade $(\varepsilon)$ deverá ser calculada, considerando a $\mathrm{P}_{\mathrm{v}}$.

$N D V I=\frac{N I R(\text { banda } 5)-V I S(\text { banda } 4)}{N I R(\text { banda } 5)+V I S(\text { banda } 4)}$

4 - Cálculo da Proporção de Vegetação $\left(P_{\mathrm{v}}\right)$ :

$P_{v}=\left(\frac{N D V I-N D V I_{\text {mín }}}{N D V I_{\text {máx }}-N D V I_{\text {máx }}}\right)^{2}$

Em que:

NDVImín e NDVImáx são os menores e maiores valores, respectivamente, encontrados na imagem resultante do NDVI.

5 - Cálculo da Emissividade da Superfície da Terra $(\varepsilon)$ : 
A Emissividade é calculada a partir da Equação de Plank invertida, proposta para um corpo negro, segundo a Equação (5).

$\varepsilon=0,004 \times P_{v}+0,986$

6 - Cálculo da Temperatura da Superfície da Terra (TS)

Finalmente, a TS é obtida com base na Equação (6):

$T S=\frac{B T}{\left\{1+\left[\left(\frac{\lambda B T}{\rho}\right) \ln (\varepsilon)\right]\right\}}$

Em que:

BT é a temperatura de brilho $\left({ }^{\circ} \mathrm{C}\right)$;

$\lambda$ é o comprimento de onda da Radiância emitida. No caso da banda 10 (10,6 - 11,2 $\mu \mathrm{m})$, o valor central é $10,9 \mu \mathrm{m}$;

$\varepsilon$ é a emissividade;

$\rho=h \frac{c}{\sigma}=14388 \mu m$

Em que:

h é a constante de Plank $\left(6,626 \times 10^{-34} \mathrm{Js}\right)$;

c é a velocidade da luz $\left(2,998 \times 10^{8} \mathrm{~m} / \mathrm{s}\right)$;

$\sigma$ é a constante de Boltzmann $\left(1,38 \times 10^{-23} \mathrm{~J} / \mathrm{K}\right)$.

Cabe ressaltar que as imagens termais do Landsat 8 apresentaram anomalias devido à dispersão da luz difusa que chega ao sensor, o que ocasionou problemas de calibração nas imagens do satélite (NASA, 2014).

Por isso as imagens de temperatura de superfície foram classificadas e foi aplicada uma escala cromática de pseudocor às imagens resultantes, com o intuito de melhor identificar o comportamento da temperatura dos alvos nas imagens. Outro detalhe importante de ser mencionado diz respeito à ausência da imagem de julho de 2018, para estes meses as imagens estão no catálogo de busca, mas quando se realiza o download das mesmas essas não existem na realidade.

Os dados diários terrestres de temperatura de 24/06/2016 a 02/09/2018 foram adquiridos através do Banco de Dados Meteorológicos para Ensino e Pesquisa (BDMEP) do Instituto Nacional de Meteorologia (INMET), referente a estação meteorológica de Aragarças-GO, Latitude $15^{\circ}, 09^{\prime} 00^{\prime \prime}$ Sul e de longitude $52^{\circ}, 02^{\prime} 03^{\prime \prime}$ Oeste, altitude a 345 metros, instalada no município vizinho. Os mesmos não apresentaram ausência de registro, descartando-se a necessidade de ser realizado recobrimento de falha (INSTITUTO NACIONAL DE METEOROLOGIA, 2019).

Posteriormente os dados diários foram organizados em planilha eletrônica e, em seguida, foram extraídas as médias mensais dessa variável meteorológica para os meses selecionados no estudo, que corresponde ao período seco na área do Cerrado. 


\section{RESULTADOS E DISCUSSÃO}

A cidade de Barra do Garças teve a sua origem com os nativos Bororos e Xavantes que viviam da caça e da coleta. Ainda no período colonial, com a chegada dos garimpeiros em busca de diamantes, ocorreu o povoamento e o posterior surgimento da cidade 'as margens dos rios Araguaia e Garças (SIQUEIRA, 2002). Hoje a cidade de Barra do Garças está em processo de expansão horizontal e vertical, a área central e os bairros de ocupação mais antiga verticalizam-se desde 1960, concentrando os serviços bancários, as lojas comerciais, cinema e os serviços de administração, cultura, recreação e saúde (MORENO; HIGA, 2005).

Lombardo (1985), afirma que, entretanto, a reorganização urbana não vem seguida da preocupação com a qualidade ambiental. Com o surgimento de novos bairros e abertura de novas áreas de expansão a dinâmica do clima urbano tem sido afetada de forma impensada. Sabe-se que uma das várias consequências é o aparecimento de áreas mais aquecidas, apresentando temperaturas de superfície elevadas nas cidades.

Jensen (2009), ressalta que as informações sobre temperatura superficial podem ser obtidas por sensoriamento remoto, tendo em vista que o calor interno de um objeto é convertido em energia radiante e para a maioria dos objetos existe uma alta correlação positiva entre a temperatura cinética verdadeira do objeto e o fluxo radiante proveniente dos objetos

Segundo Nimer (1989) a mesorregião de Barra do Garças está na porção leste do estado de Mato Grosso. De acordo com a classificação climática de Köppen, o clima típico da região é classificado como Aw (megatérmico: tropical com verão chuvoso e inverno seco), a estação chuvosa é bem definida no período de outubro a abril e há um período seco de maio a setembro; com temperaturas médias entre $14^{\circ} \mathrm{C}$ em junho e $31^{\circ} \mathrm{C}$ em dezembro. Outro fator importante a ser mencionado é que não é comum a ocorrência de geadas

De modo que Ab'Saber e Costa (1948) lembram que os meses de maio a setembro são relativamente secos com a mínima em julho, enquanto de outubro a abril as precipitações são abundantes, com o máximo no solstício de verão, isso devido à localização geográfica da porção Centro-Oeste do Brasil, nas áreas tropicais de continentalidade pronunciada, dotadas de um longo período chuvoso durante 0 ano, opondo-se a um outro, mais seco, de igual duração.

Na Figura 02 consta a altimetria da área urbana da cidade de Barra do Garças-MT, encontram-se de 289 metros até 348 metros de altitude, sendo que os bairros se encontram na porção oeste: Abel Lira, Nova Barra Sul, Ipês, Margarida, Mariano, Morada do Sol, Nova 
Barra do Garças, Nova Barra Norte, Novo Horizonte, Ouro Fino, Palmares, Paraíso, Piracema, São Conrado, Tamburi, Toledo, Vila Maria, Wilmar Peres e Zeca Ribeiro. Porção Norte: Cohab, Pitaluga, Serrinha, União, Vila Santo Antônio e Vila Varjão. Porção Sul: Campinas, Centro, Cidade Universitária, São Benedito, São João, São Paulo, São Sebastião e Sena Marques. Porção Leste: Amazônia I, Amazônia II, Anchieta, BNH, Dermat, Mangueiras, Morada do Sol e Recanto das Acácias.

Figura 2 - Perímetro Urbano de cidade de Barra do Garças-MT

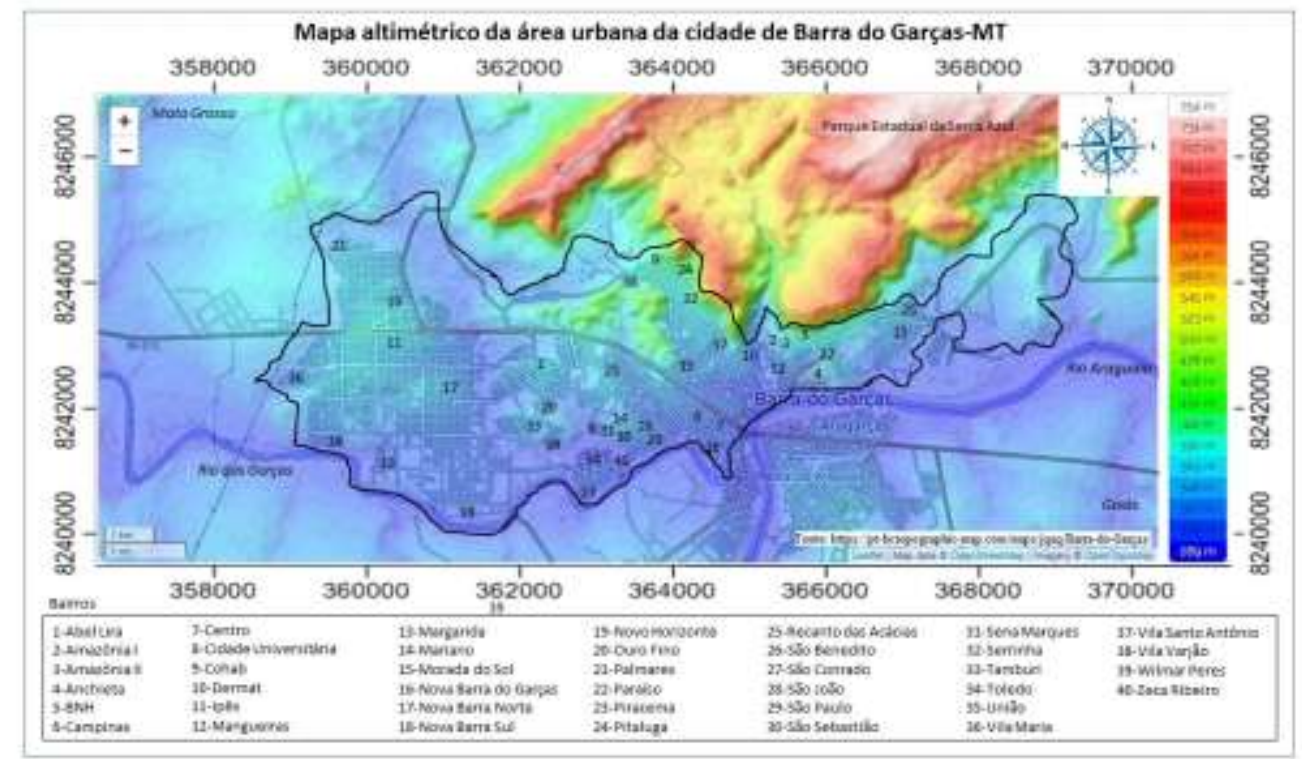

Fonte: adaptado por: R. R. de Sousa, de: Barra do Garças (2019).

O relevo de Barra do Garças caracteriza-se por feições morfológicas complexas, dentro da depressão do Araguaia, com relevo fragmentado em blocos resultantes de ação tectônica, apresentando patamares delimitados por escarpas e blocos residuais com topos tabulares reduzidos e vertentes abruptas, entende-se paralelamente à Planície do Araguaia, configurando-se como uma vasta área rebaixada com altitudes variando de 200 a 300 metros e apresentando-se tenuamente dissecado (ROSS; VASCONCELOS; CASTRO JÚNIOR, 2005).

$\mathrm{Na}$ imagem termal referente a junho de 2016 , o maior valor de temperatura, com $35^{\circ} \mathrm{C}$, foi registrado nos seguintes bairros: São Conrado, Toledo e Zeca Ribeiro, sendo que estes bairros estão no início da porção oeste (Figura 03). Já os valores de $29^{\circ} \mathrm{C}$ até $33^{\circ} \mathrm{C}$ aconteceram no restante da porção oeste, nos bairros: Abel Lira, Barra Sul, Ipês, Margarida, Mariano, Morada do Sol, Nova Barra do Garças, Nova Barra Norte, Nova Barra Sul, Novo Horizonte, Ouro Fino, Palmares, Paraíso, Piracema, São Conrado, Tamburi, Toledo, Vila Maria, Wilmar Peres e em parte do extremo leste: bairros Anchieta, Morada do Sol e Recanto das Acácias. 
Neste sentido, notou-se que, na Figura 03, os menores valores de temperaturas com $23^{\circ} \mathrm{C}$ até $27^{\circ} \mathrm{C}$ foram quantificados nas porções norte, sul e restante do leste, mais precisamente nos bairros: Cohab, Pitaluga, Serrinha, União, Vila Santo Antônio, Vila Varjão, Campinas, Centro, Cidade Universitária, São Benedito, São João, São Paulo, São Sebastião, Sena Marques, Amazônia I, Amazônia II, Anchieta, BNH, Dermat e Mangueiras.

Figura 03 - Imagem termal 24 de junho de 2016

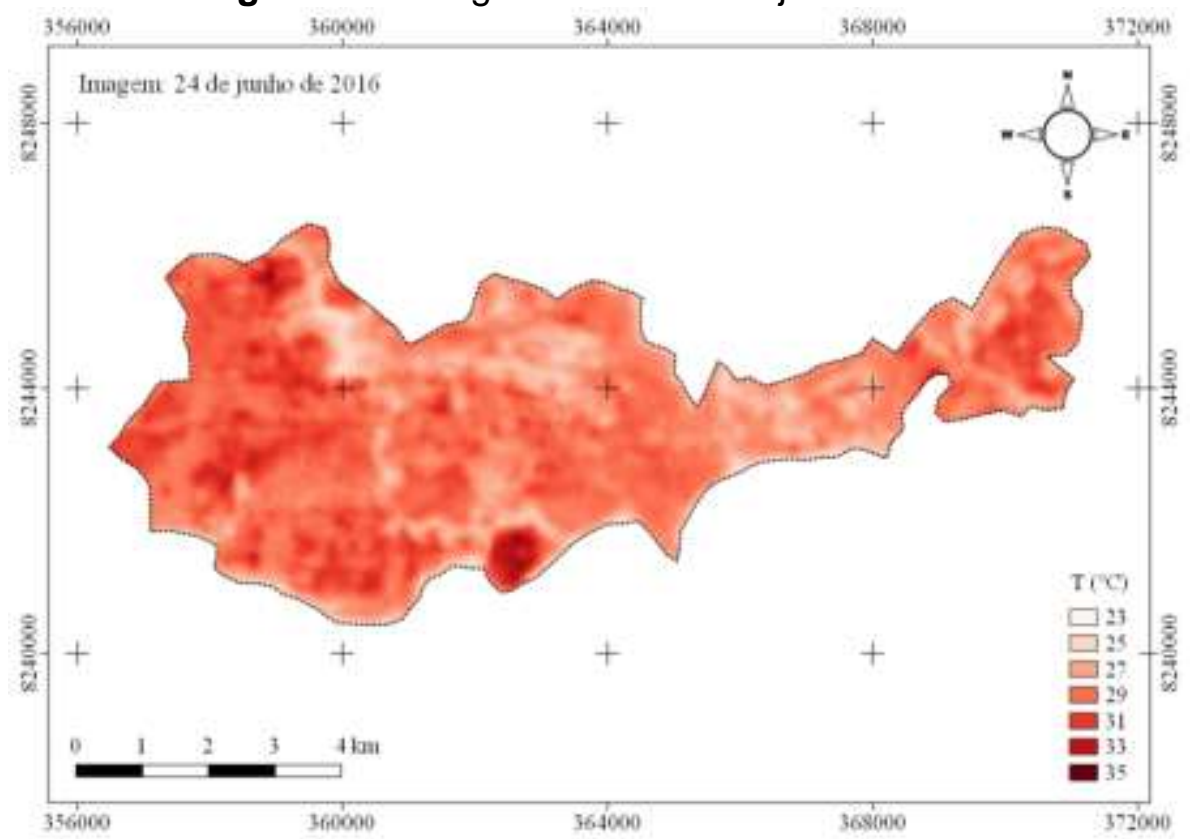

Elaboração: R. R. de Sousa (2020). Fonte: dados da pesquisa.

Averiguou-se no início da porção oeste o maior valor de $38^{\circ} \mathrm{C}$, registrado nos bairros: São Conrado, Toledo e Zeca Ribeiro (Figura 04). Em contrapartida, valores de $30^{\circ} \mathrm{C}$ até $36^{\circ} \mathrm{C}$ estiveram presentes no restante da porção oeste e no extremo leste, nos bairros: Abel Lira, Barra Sul, Ipês, Margarida, Mariano, Morada do Sol, Nova Barra do Garças, Nova Barra Norte, Nova Barra Sul, Novo Horizonte, Ouro Fino, Palmares, Paraíso, Piracema, São Conrado, Tamburi, Toledo, Vila Maria, Wilmar Peres, Anchieta, Morada do Sol e Recanto das Acácias. Nas porções norte, sul e no restante do leste, os valores foram de $24^{\circ} \mathrm{C}$ até 28ํㅡ, nos seguintes bairros: Cohab, Pitaluga, Serrinha, União, Vila Santo Antônio, Vila Varjão, Campinas, Centro, Cidade Universitária, São Benedito, São João, São Paulo, São Sebastião, Sena Marques, Amazônia I, Amazônia II, Anchieta, BNH, Dermat e Mangueiras.

Examinando a Figura 04, o restante da porção oeste também apresentou valores elevados de temperatura, de $28^{\circ} \mathrm{C}$ até $34^{\circ} \mathrm{C}$, nos bairros: Abel Lira, Ipês, Margarida, Mariano, Morada do Sol, Nova Barra do Garças, Nova Barra Norte, Nova Barra Sul, Novo Horizonte, Ouro Fino, Palmares, Paraíso, Piracema, São Conrado, Tamburi, Toledo, Vila Maria e Wilmar Peres. O maior valor de temperatura, $\operatorname{com}^{3} 8^{\circ} \mathrm{C}$, foi quantificado nos bairros: 
São Conrado, Toledo e Zeca Ribeiro, sendo que estes bairros estão no início da porção oeste e nos bairros no extremo leste: Anchieta, Morada do Sol e Recanto das Acácias.

Figura 04 - Imagem termal 26 de julho de 2016

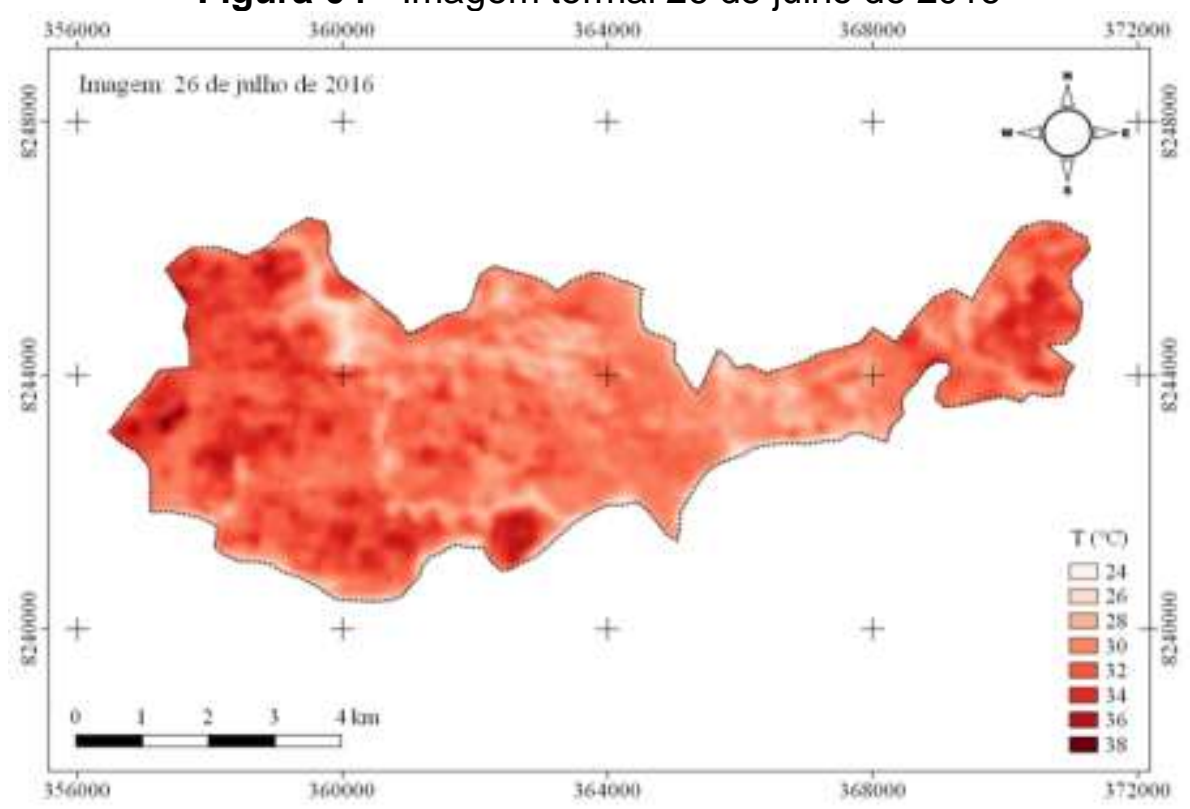

Elaboração: R. R. de Sousa (2020). Fonte: dados da pesquisa.

$\mathrm{Na}$ Figura 05 observam-se as porções norte, sul e parte restante do leste, onde as temperaturas se manifestaram menos elevadas, com valores de $22^{\circ} \mathrm{C}$ até $26^{\circ} \mathrm{C}$. As variações das temperaturas aconteceram nos seguintes bairros: Cohab, Pitaluga, Serrinha, União, Vila Santo Antônio, Vila Varjão, Campinas, Centro, Cidade Universitária, São Benedito, São João, São Paulo, São Sebastião, Sena Marques, Amazônia I, Amazônia II, Anchieta, BNH, Dermat e Mangueiras.

Nas porções oeste e no restante de leste registraram-se valores de $28^{\circ} \mathrm{C}$ até $34^{\circ} \mathrm{C}$, e nos seguintes bairros: Abel Lira, Barra Sul, Ipês, Margarida, Mariano, Morada do Sol, Nova Barra do Garças, Nova Barra Norte, Nova Barra Sul, Novo Horizonte, Ouro Fino, Palmares, Paraíso, Piracema, São Conrado, Tamburi, Toledo, Vila Maria, Wilmar Peres, Amazônia I, Amazônia II, Anchieta, BNH, Dermat e Mangueiras. Por outro lado, o maior valor de $36^{\circ} \mathrm{C}$ foi confirmado nos bairros São Conrado, Toledo e Zeca Ribeiro, estes estando no início da porção oeste.

Na Figura 06, referente à imagem termal de 28 de setembro de 2016, o maior valor de temperatura foi registrado no início da porção oeste, com $44^{\circ} \mathrm{C}$, ocorrendo nos bairros: São Conrado, Toledo e Zeca Ribeiro. Para o restante da porção oeste e no extremo leste da área de estudo as temperaturas se apresentaram de $36^{\circ} \mathrm{C}$ a $42^{\circ} \mathrm{C}$, nos bairros: Abel Lira, Barra Sul, Ipês, Margarida, Mariano, Morada do Sol, Nova Barra do Garças, Nova Barra Norte, Nova Barra Sul, Novo Horizonte, Ouro Fino, Palmares, Paraíso, Piracema, São 
Conrado, Tamburi, Toledo, Vila Maria, Wilmar Peres, Anchieta, Morada do Sol e Recanto das Acácias.

Figura 05 - Imagem termal 11 de agosto de 2016

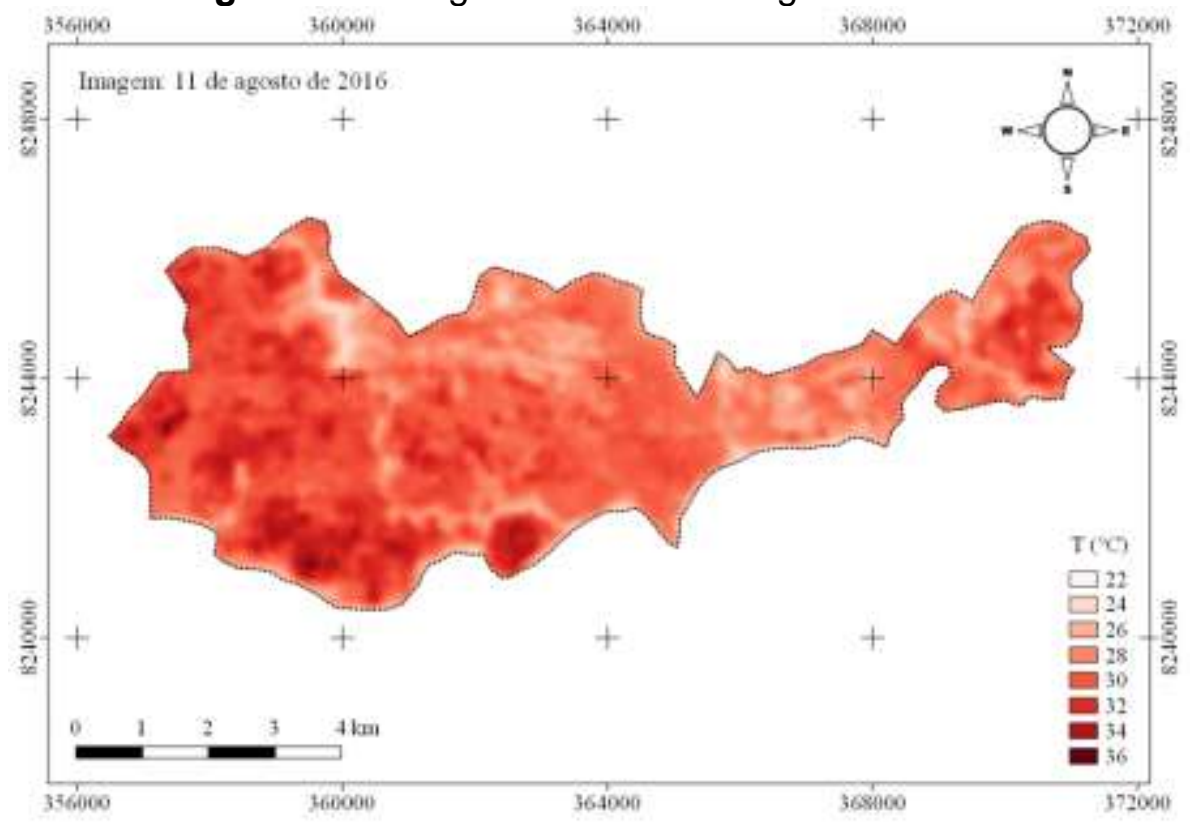

Elaboração: R. R. de Sousa (2020). Fonte: dados da pesquisa.

Figura 06 - Imagem termal 28 de setembro de 2016

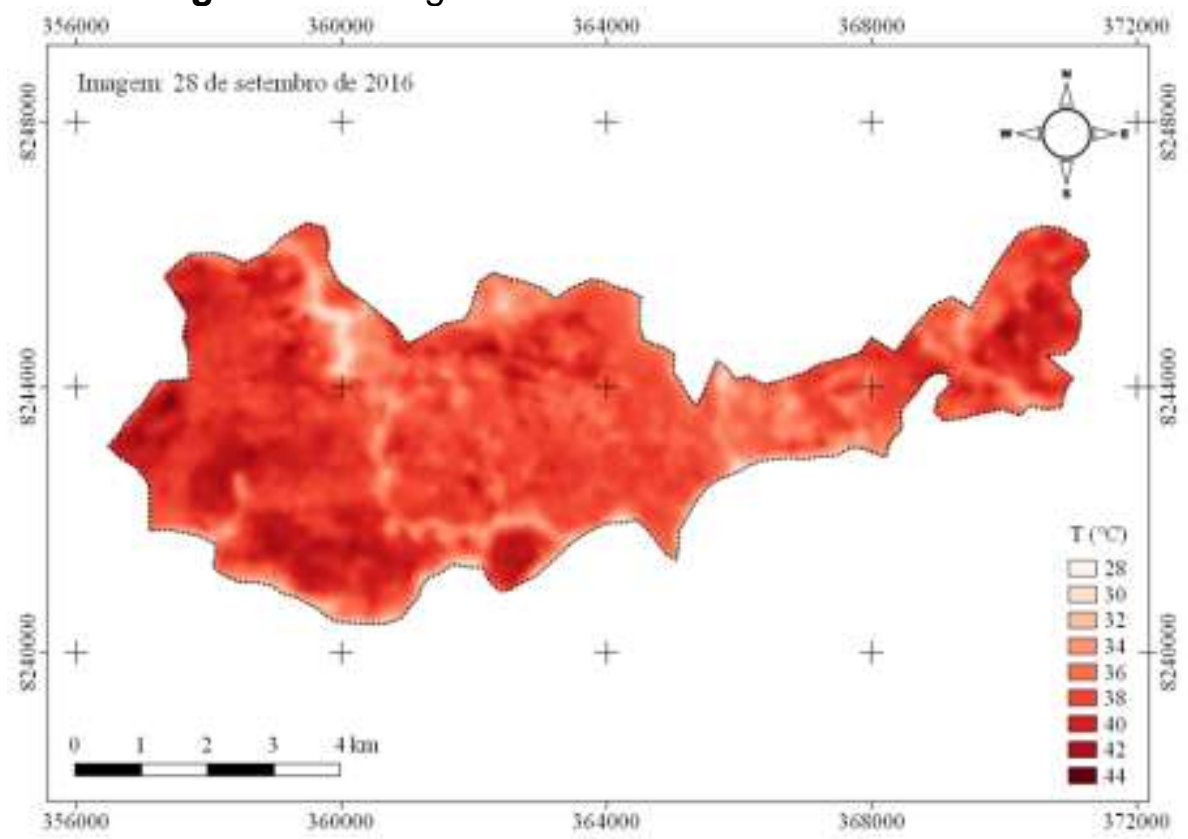

Elaboração: R. R. de Sousa (2020). Fonte: dados da pesquisa.

Com valores de $28^{\circ} \mathrm{C}$ até $34^{\circ} \mathrm{C}$, as temperaturas foram confirmadas nas porções norte, sul e no restante de leste, nos bairros: Cohab, Pitaluga, Serrinha, União, Vila Santo Antônio, Vila Varjão, Campinas, Centro, Cidade Universitária, São Benedito, São João, São Paulo, 
São Sebastião, Sena Marques, Amazônia I, Amazônia II, Anchieta, BNH, Dermat e Mangueiras.

Observando a Figura 07, que se refere às temperaturas de 11 de junho de 2017, os maiores valores de temperaturas, de $27^{\circ} \mathrm{C}$ até $31^{\circ} \mathrm{C}$, foram visualizados no oeste, sul e no extremo leste, nos bairros: Abel Lira, Ipês, Margarida, Mariano, Morada do Sol, Nova Barra do Garças, Nova Barra Norte, Nova Barra Sul, Novo Horizonte, Ouro Fino, Palmares, Paraíso, Piracema, São Conrado, Tamburi, Toledo, Vila Maria, Wilmar Peres, Campinas, Centro, Cidade Universitária, São Benedito, São João, São Paulo, São Sebastião, Sena Marques, Anchieta, Morada do Sol e Recanto das Acácias.

Figura 07 - Imagem termal 11 de junho de 2017

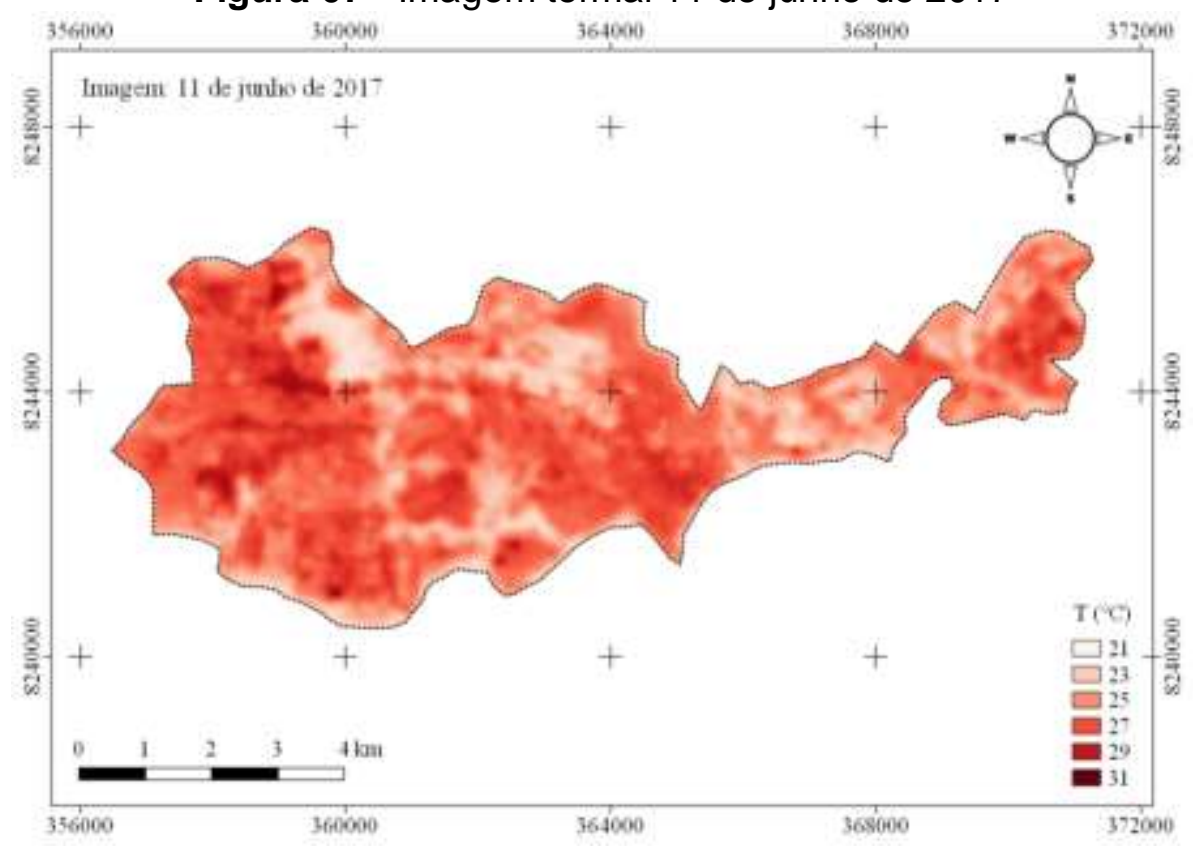

Elaboração: R. R. de Sousa (2020). Fonte: dados da pesquisa.

Neste sentido, a análise aponta para o fato de que as temperaturas de $21^{\circ} \mathrm{C}$ até $25^{\circ} \mathrm{C}$ aconteceram nas porções norte e no restante da porção leste nos bairros: Cohab, Pitaluga, Serrinha, União, Vila Santo Antônio, Vila Varjão, Amazônia I, Amazônia II, Anchieta, BNH, Dermat e Mangueiras.

Visualizou-se, na Figura 08, referente a 13 de julho de 2017, que os maiores valores, de $34^{\circ} \mathrm{C}$ até $36^{\circ} \mathrm{C}$, aconteceram na porção oeste e no extremo leste, sendo nos bairros: Abel Lira, Ipês, Margarida, Mariano, Morada do Sol, Nova Barra do Garças, Nova Barra Norte, Nova Barra Sul, Novo Horizonte, Ouro Fino, Palmares, Paraíso, Piracema, São Conrado, Tamburi, Toledo, Vila Maria, Wilmar Peres, Anchieta, Morada do Sol e Recanto das Acácias.

Com os valores de $22^{\circ} \mathrm{C}$ até $32^{\circ} \mathrm{C}$, estes valores estiveram presentes nas porções norte, sul e no restante do leste nos bairros: Cohab, Pitaluga, Serrinha, União, Vila Santo Antônio, Vila Varjão, Campinas, Centro, Cidade Universitária, São Benedito, São João, São 
Paulo, São Sebastião, Sena Marques, Amazônia I, Amazônia II, Anchieta, BNH, Dermat e Mangueiras.

Figura 08 - Imagem termal 13 de julho de 2017

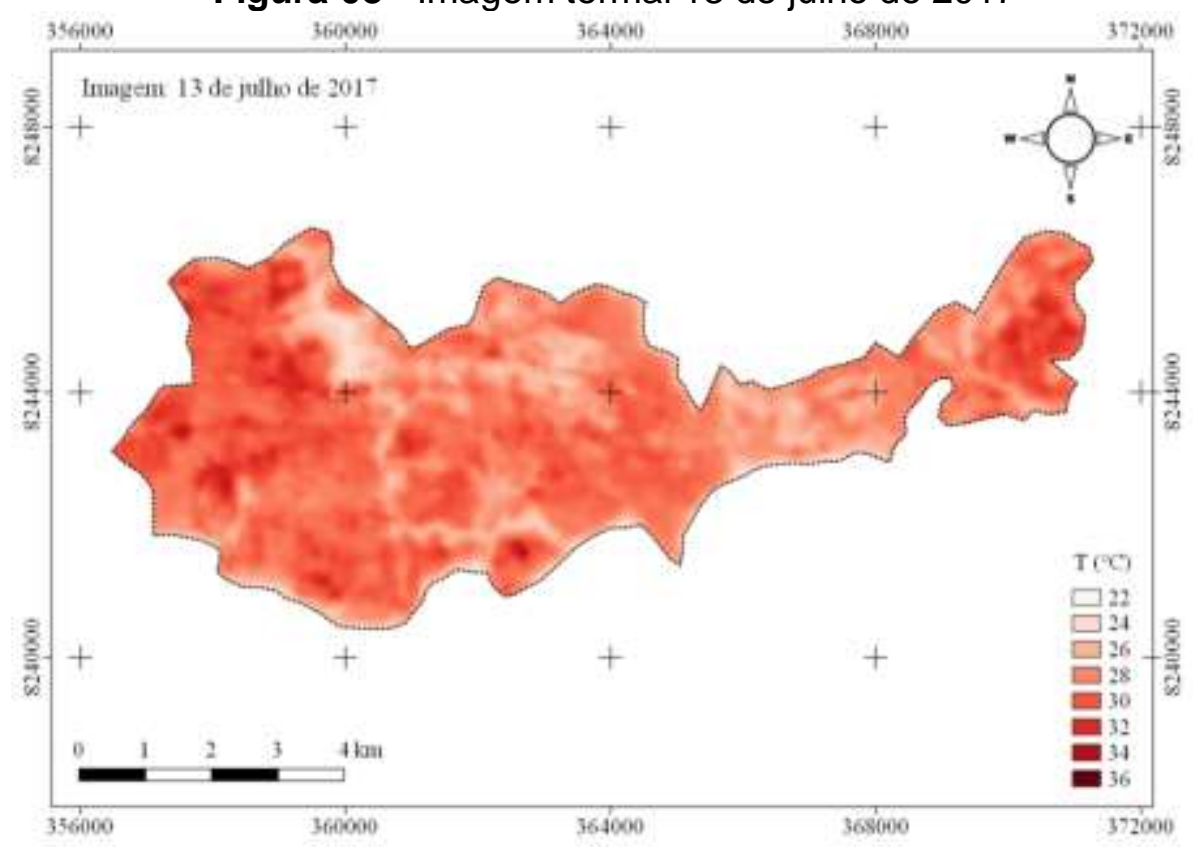

Elaboração: R. R. de Sousa (2020). Fonte: dados da pesquisa.

Averiguou-se na Figura 09, referente a 30 de agosto de 2017, que os maiores valores, de $41^{\circ} \mathrm{C}$ até $45^{\circ} \mathrm{C}$, aconteceram na porção oeste e no extremo leste, mais precisamente nos bairros: Abel Lira, Ipês, Margarida, Mariano, Morada do Sol, Nova Barra do Garças, Nova Barra Norte, Nova Barra Sul, Novo Horizonte, Ouro Fino, Palmares, Paraíso, Piracema, São Conrado, Tamburi, Toledo, Vila Maria, Wilmar Peres, Anchieta, Morada do Sol e Recanto das Acácias.

Para as porções norte, sul e no restante do leste os valores diminuíram e foram quantificados de $27^{\circ} \mathrm{C}$ até $39^{\circ} \mathrm{C}$, e se destacaram os bairros: Cohab, Pitaluga, Serrinha, União, Vila Santo Antônio, Vila Varjão, Campinas, Centro, Cidade Universitária, São Benedito, São João, São Paulo, São Sebastião, Sena Marques, Amazônia I, Amazônia II, Anchieta, BNH, Dermat e Mangueiras.

$\mathrm{Na}$ Figura 10, referente às temperaturas de 15 de setembro de 2017 , os maiores valores, de $42^{\circ} \mathrm{C}$ até $48^{\circ} \mathrm{C}$, aconteceram nas porções oeste e no extremo leste, nos bairros: Abel Lira, Barra Sul, Ipês, Margarida, Mariano, Morada do Sol, Nova Barra do Garças, Nova Barra Norte, Nova Barra Sul, Novo Horizonte, Ouro Fino, Palmares, Paraíso, Piracema, São Conrado, Tamburi, Toledo, Vila Maria, Wilmar Peres, Anchieta, Morada do Sol e Recanto das Acácias. 
Figura 09 - Imagem termal 30 de agosto de 2017

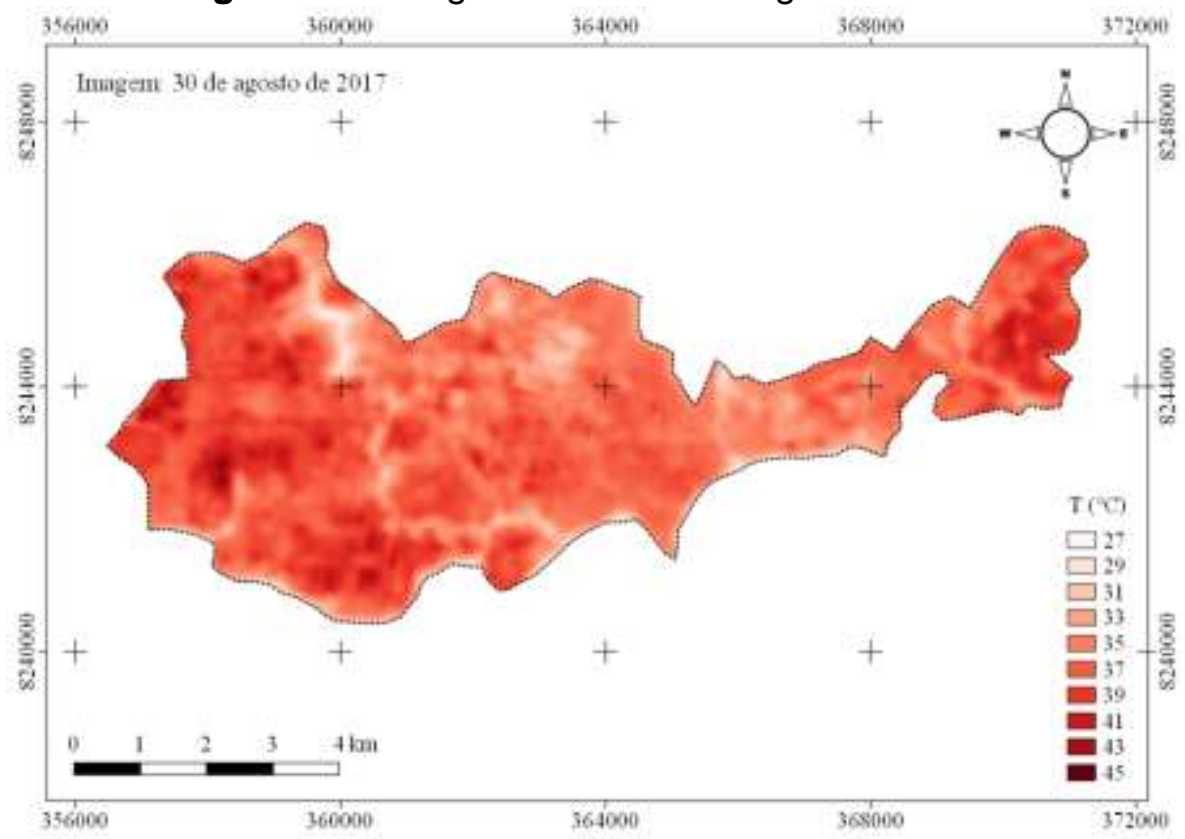

Elaboração: R. R. de Sousa (2020). Fonte: dados da pesquisa.

Figura 10 - Imagem termal 15 de setembro de 2017

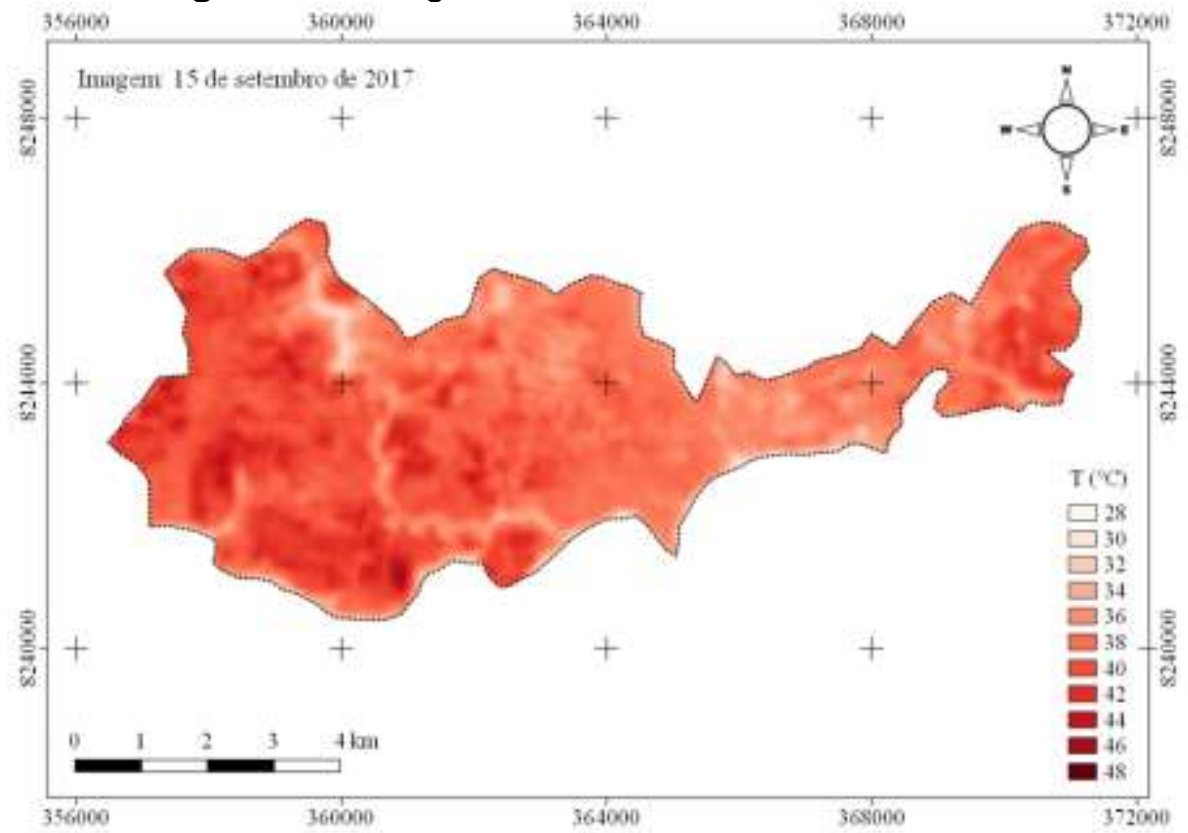

Elaboração: R. R. de Sousa (2020). Fonte: dados da pesquisa.

Em contrapartida os valores diminuíram nas porções norte, sul e no restante do leste com confirmações de $2^{\circ} \mathrm{C}$ até $40^{\circ} \mathrm{C}$, presentes nos bairros: Cohab, Pitaluga, Serrinha, União, Vila Santo Antônio, Vila Varjão, Campinas, Centro, Cidade Universitária, São Benedito, São João, São Paulo, São Sebastião, Sena Marques, Amazônia I, Amazônia II, Anchieta, BNH, Dermat e Mangueiras.

Apurou-se, na Figura 11, referente as temperaturas de 14 de junho de 2018, os maiores valores, de $28^{\circ} \mathrm{C}$ até $32^{\circ} \mathrm{C}$, nas porções oeste, sul e no extremo leste, assim se 
destacaram os bairros: Abel Lira, Ipês, Margarida, Mariano, Morada do Sol, Nova Barra do Garças, Nova Barra Norte, Nova Barra Sul, Novo Horizonte, Ouro Fino, Palmares, Paraíso, Piracema, São Conrado, Tamburi, Toledo, Vila Maria, Wilmar Peres, Campinas, Centro, Cidade Universitária, São Benedito, São João, São Paulo, São Sebastião, Sena Marques, Anchieta, Morada do Sol e Recanto das Acácias.

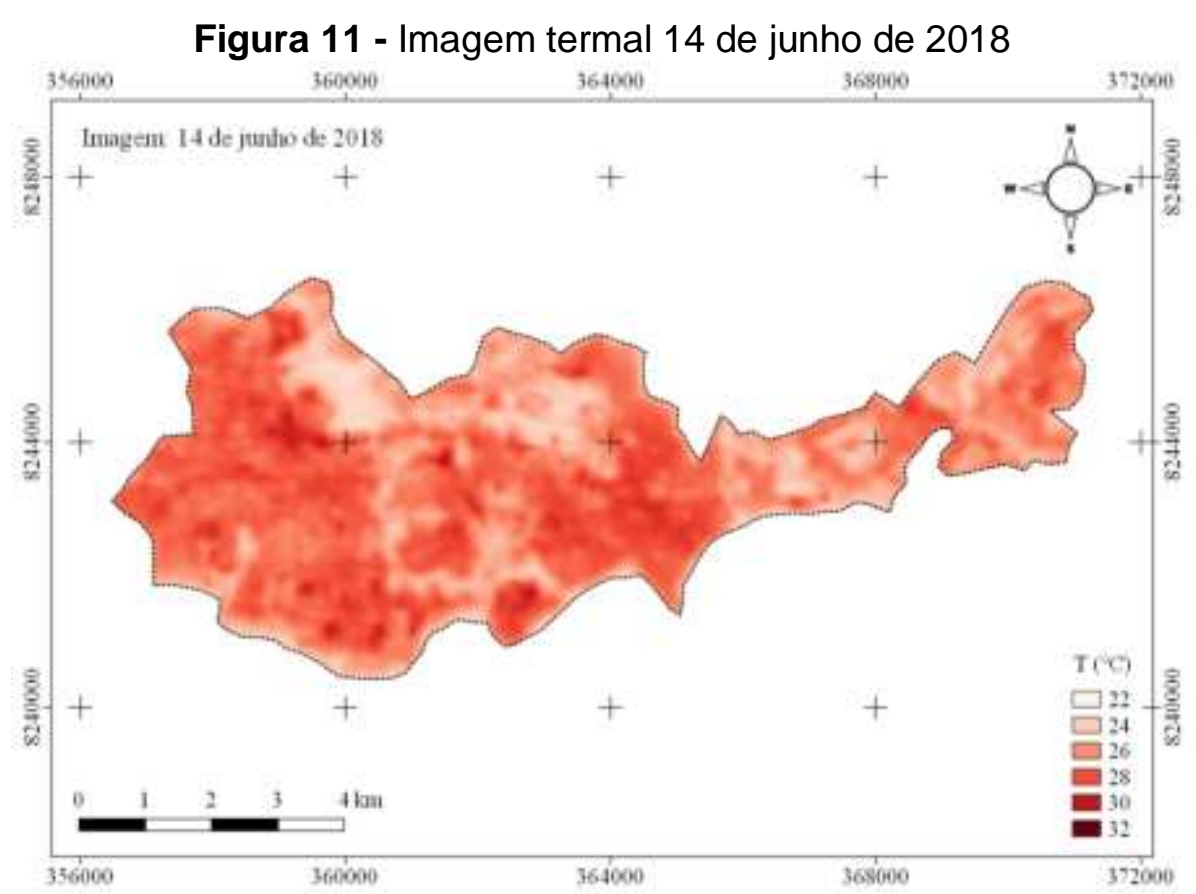

Elaboração: R. R. de Sousa (2020). Fonte: dados da pesquisa.

$\mathrm{Na}$ porção norte e no restante do leste os valores diminuíram, quantificados de $22^{\circ} \mathrm{C}$ até $30^{\circ} \mathrm{C}$, nos bairros: Cohab, Pitaluga, Serrinha, União, Vila Santo Antônio, Vila Varjão, Amazônia I, Amazônia II, Anchieta, BNH, Dermat e Mangueiras.

Ponderou-se, na Figura 12, referente às temperaturas de 01 de agosto de 2018, que os maiores valores aconteceram nas porções oeste, sul e no extremo leste, com registros de $30^{\circ} \mathrm{C}$ até $34^{\circ} \mathrm{C}$, sendo que estes valores aconteceram nos bairros: Abel Lira, Ipês, Margarida, Mariano, Morada do Sol, Nova Barra do Garças, Nova Barra Norte, Nova Barra Sul, Novo Horizonte, Ouro Fino, Palmares, Paraíso, Piracema, São Conrado, Tamburi, Toledo, Vila Maria, Wilmar Peres, Campinas, Centro, Cidade Universitária, São Benedito, São João, São Paulo, São Sebastião, Sena Marques, Anchieta, Morada do Sol e Recanto das Acácias.

Os valores diminuíram nas porções norte e no restante do leste, valores registrados de $22^{\circ} \mathrm{C}$ até $28^{\circ} \mathrm{C}$, nos bairros: Cohab, Pitaluga, Serrinha, União, Vila Santo Antônio, Vila Varjão, Amazônia I, Amazônia II, Anchieta, BNH, Dermat e Mangueiras. 


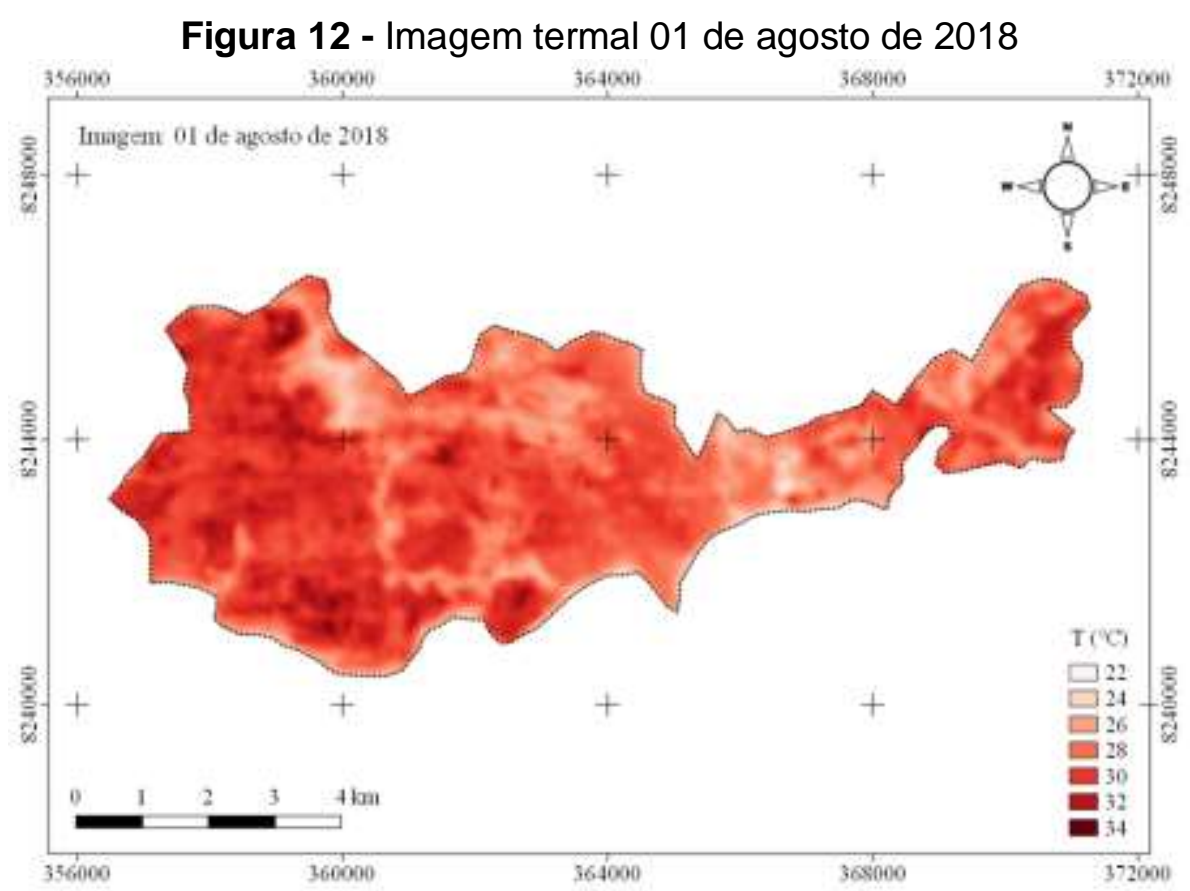

Elaboração: R. R. de Sousa (2020). Fonte: dados da pesquisa.

$\mathrm{Na}$ Figura 13, referente a 02 de setembro de 2018, os valores mais expressivos e elevados aconteceram nas porções oeste, parte do norte, sul e extremo leste, de $32^{\circ} \mathrm{C}$ até $38^{\circ} \mathrm{C}$. As oscilações das temperaturas apresentaram-se nos seguintes bairros: Abel Lira, Ipês, Margarida, Mariano, Morada do Sol, Nova Barra do Garças, Nova Barra Norte, Nova Barra Sul, Novo Horizonte, Ouro Fino, Palmares, Paraíso, Piracema, São Conrado, Tamburi, Toledo, Vila Maria, União, Wilmar Peres, Zeca Ribeiro, Campinas, Centro, Cidade Universitária, São Benedito, São João, São Paulo, São Sebastião, Sena Marques, Anchieta, Morada do Sol e Recanto das Acácias.

Finalizando a análise da Figura 13 , os valores de $24^{\circ} \mathrm{C}$ até $30^{\circ} \mathrm{C}$ se apresentaram no extremo norte e no restante da porção leste. Expressivamente diante da variação das temperaturas o menor valor registrado com $24^{\circ} \mathrm{C}$ aconteceu nos seguintes bairros: Cohab, Pitaluga, Serrinha, Vila Santo Antônio, Vila Varjão, Amazônia I, Amazônia II, Anchieta, BNH, Dermat e Mangueiras.

Mediante a análise observada nas imagens termal para o período em questão, visualizou-se que o mês de setembro registrou os maiores valores, 2017 com $48^{\circ} \mathrm{C}, 2016$ com $44^{\circ} \mathrm{C}$ e $2018 \mathrm{com}^{3} 8^{\circ} \mathrm{C}$.

As cidades brasileiras apresentam problemas sérios quanto à questão ambiental, evidenciando-se a presença de ilhas de calor e ilhas de frescor, de conforto e desconforto térmico, tendo o vento como o dispersor da poluição. Dessa forma, tem-se apontado como causador e acelerador dos fenômenos climáticos o adensamento humano e urbano nas atividades diárias no meio urbano e rural (LOMBARDO, 1985). 
Figura 13 - Imagem termal 02 de setembro de 2018

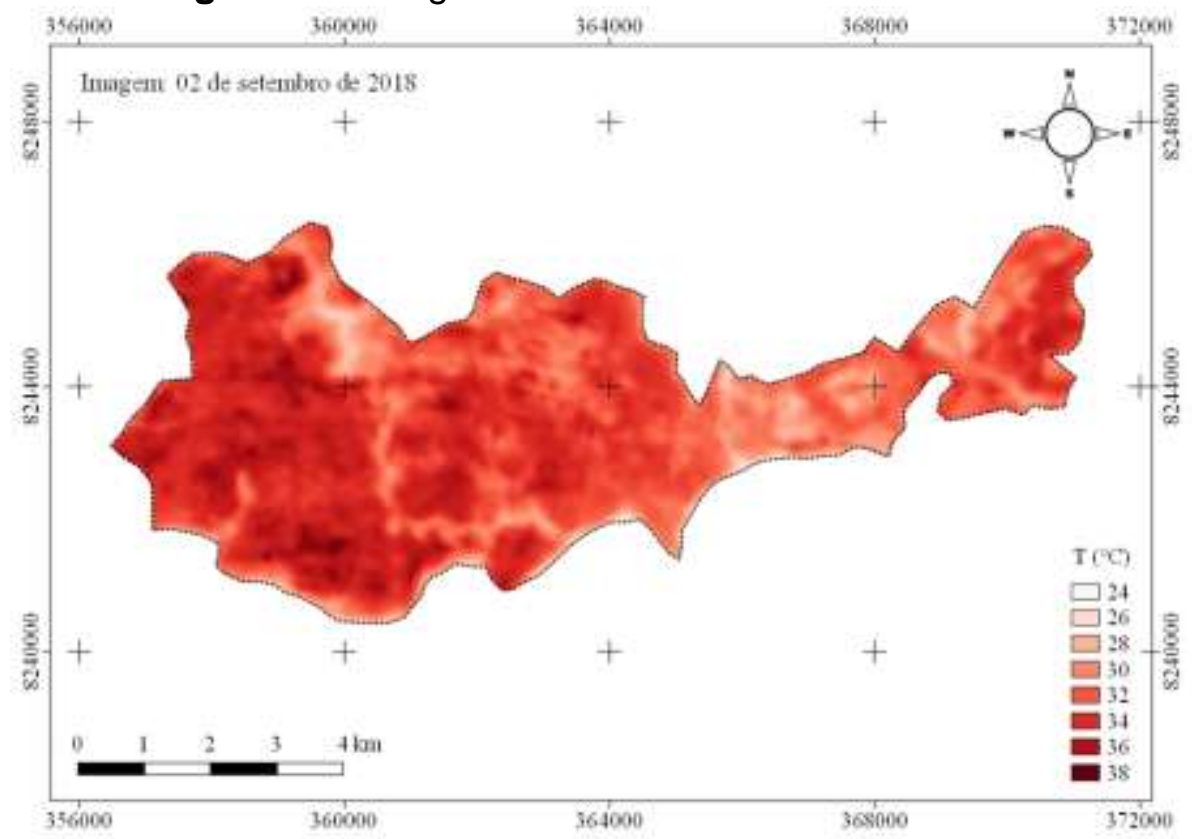

Elaboração: R. R. de Sousa (2020). Fonte: dados da pesquisa.

Neste contexto segundo Melo (2016), a omissão e/ou displicência em relação ao tempo necessário para que a natureza se recupere dos impactos antrópicos desencadeia uma projeção geométrica de intervenções no meio, tendo como consequências modificações incisivas em toda sua dinâmica, afetando o homem de forma latente em seus processos de ocupação do espaço.

Diante de toda a análise efetuada, observando-se os dados do Banco de Dados Meteorológicos para Ensino e Pesquisa - BDMEP (INSTITUTO NACIONAL DE METEOROLOGIA, 2019), referente à estação meteorológica de Aragarças-GO (Tabela 01), averiguou-se que para o período estudado ocorreu uma variação nas temperaturas do ar, e o mês de setembro se apresentou como o mês mais aquecido para os anos de 2016 com $29,3^{\circ} \mathrm{C}, 2017 \operatorname{com} 28,6^{\circ} \mathrm{C}$ e $2018 \mathrm{com} 27,1^{\circ} \mathrm{C}$.

Tabela 01 - Dados da estação meteorológica.

\begin{tabular}{llll}
\hline Mês Ano & $\mathbf{2 0 1 6}$ & $\mathbf{2 0 1 7}$ & $\mathbf{2 0 1 8}$ \\
\hline Abril & 28,2 & 27,5 & 25,9 \\
Maio & 27,0 & 26,5 & 24,8 \\
Junho & 24,9 & 25,0 & 24,0 \\
Julho & 24,7 & 23,1 & 23,5 \\
Agosto & 26,6 & 27,2 & 26,5 \\
Setembro & 29,3 & 28,6 & 27,1 \\
\hline
\end{tabular}

Fonte: organizado por: R. R. de Sousa, de: Instituto Nacional de Meteorologia (2019).

É importante ressaltar que a estação meteorológica de Aragarças-GO instalada ao lado do aeroporto de Aragarças-GO, está em um local amplamente aberto e de pequena 
densidade urbana da cidade de Aragarças. (INSTITUTO NACIONAL DE METEOROLOGIA, 2019).

Outro detalhe que chamou a atenção, conforme a Tabela 01, diz respeito ao mês de julho que apresentou as temperaturas mais amenas; em 2017 exibiu 23,1ํㅡ, $2018 \mathrm{com}$ $23,5^{\circ} \mathrm{C}$ e $2016 \mathrm{com} 24,7^{\circ} \mathrm{C}$. Segundo Cavalcanti e Kousky (2009) existe uma sazonalidade na ocorrência de passagens de frentes frias no Brasil. Na região Centro-Oeste são mais frequentes de maio a setembro, ocasionando a queda de temperatura, principalmente nos meses de maio a agosto.

Nimer (1989) argumenta que enquanto no verão o calor é quase uma constante, no inverno, devido à continentalidade da região Centro-Oeste e da consequente secura do ar, são comuns dias muito frios, sobretudo em junho e julho, e nestes meses costumam ocorrer, também, temperaturas relativamente elevadas, quando as massas frias de origem polar ficam ausentes por muitos dias. Por essa razão, as médias mensais dos invernos são relativamente altas, escamoteando a ocorrência de dias muito frios nessa época.

De acordo com Sette e Tarifa (2000), o estado de Mato Grosso apresenta a sua estação seca de abril a setembro, quando atua o Subsistema Tropical Atlântico Continentalizado (TAC), com "ápice" de estabilidade e frequência em junho, julho, agosto e setembro, quando inicia o movimento contrário, a retirada progressiva desse sistema do Brasil Central, indicando uma nova mudança estacional - a primavera, e a estação chuvosa de outubro a março, tendo a Zona de Convergência do Atlântico Sul (ZCAS) atuante neste período. Toda a dinâmica climática ignorada juntamente com o processo de apropriação da natureza pelo homem tem causado diversos problemas no contexto da biosfera, a exemplo cita-se degradação dos solos, perda de espécies, poluição do ar, aquecimento de superfície e variação de temperaturas (GOIS et al., 2015).

Ynoue et al. (2017) relatam que a maior parte do conhecimento sobre a estrutura física e dinâmica da atmosfera e dos oceanos é baseada em observações locais (in situ), onde coletam-se dados diários, dando uma maior credibilidade aos trabalhos.

A modificação dos componentes naturais da paisagem e sua substituição por formas urbanas resulta em vários impactos no ambiente, tanto positivos como negativos. A temperatura e a umidade relativa do ar estão entre estes indicadores de variação climática, sendo que essa interferência é notada pela variação dos elementos climáticos frente à sucessão dos tipos de tempo (MACHADO; JARDIM, 2014).

\section{CONSIDERAÇÕES FINAIS}

Percebeu-se, durante a análise, a partir da metodologia utilizada, com o uso das imagens termal do satélite Landsat 8 , que as mesmas serviram como uma excelente 
ferramenta de auxilio para entender a dinâmica da variação das temperaturas do ar dentro da area urbana da cidade de Barra do Garças, que apresentou areas mais e menos aquecidas, e que, a partir das verificações confirmadas no trabalho desenvolvido, espera-se que o poder público planeje as formas de ocupação do espaço na tentativa de oferecer qualidade de vida à população.

Assim constatou-se que as temperaturas mais elevadas aconteceram nos bairros que estão nos locais mais baixos do sítio urbano. As porções oeste, sul e extremo leste apresentaram temperaturas aquecidas e, em compensação, os valores menos elevados foram identificados na porção norte e no meio da porção leste.

Também identificou-se que os bairros São Conrado, Toledo e Zeca Ribeiro, que estão na porção oeste, e os que estão no extremo leste, como o Anchieta, Morada do Sol e Recanto das Acácias, são os aquecidos nos anos de 2016, 2017 e 2018. Dessa forma, ficou evidenciado que estes bairros estão em vertentes voltadas para o norte e por isso recebem radiação solar o dia inteiro. Como consequência registrou-se temperaturas mais elevadas.

\section{REFERÊNCIAS}

AB'SABER, Aziz Nacib; COSTA JÚNIOR, Miguel. Contribuição ao estudo do Sudoeste Goiano. Boletim Geográfico, Rio de Janeiro, RJ, v. 9, n. 2. p. 121-136, 1948.

AVDAN, Ugur; JOVANOVSKA, Gordana. Algorithm for automated mapping of Land Surface Temperature Using LANDSAT 8 Satellite Data. Journal of Sensors, London, UK, v. 2016, p. 1 - 8, article ID 1480307, 2016. Disponível em https://doi.org/10.1155/2016/1480307. Acesso em: 2 mar. 2020.

BARRA DO GARÇAS. Mato Grosso. Brasil. Mapas topográficos. 2019. Disponível em: https://pt-br.topographic-map.com/maps/jqaq/Barra-do-Garcas. Acesso em: 25 jan. 2020.

CALVALCANTI, Iracema Fonseca de; KOUSKY, Vernon E. Frentes frias sobre o Brasil. In: CALVALCANTI, Iracema Fonseca de Albuquerque et al. (orgs.). Tempo e clima no Brasil. São Paulo: Oficina de textos, 2009. p. $85-95$.

FERRETTI, Eliane Geografia em ação, práticas em climatologia. Curitiba: Aymará, 2012.

GOIS, Douglas Vieira et al. Índices de vegetação e suscetibilidade à desertificação no município de Poço Redondo-Sergipe. In: SIMPÓSIO DE GEOTECNOLOGIAS E GEOINFORMAÇÃO NO ESTADO DE ALAGOAS - GeoAlagoas, 3., 2015, Maceió, AL. Anais [...]. Maceió: Unit, 2015. p. 1-7.

IBGE. Mapas. Bases e referenciais. Bases cartográficas. Mapas municipais. Município de Barra do Garças. Rio de Janeiro, RJ: IBGE, 2016. Disponível em:

https://mapas.ibge.gov.br/bases-e-referenciais/bases-cartograficas.html. Acesso em: 15 out. 2019.

INMET - INSTITUTO NACIONAL DE METEOROLOGIA. Banco de Dados Meteorológicos para Ensino e Pesquisa - BDMEP. Brasília, DF: INMET, 2019. Disponível em: http://www.inmet.gov.br/projetos/rede/pesquisa/inicio.php. Acesso em: 29 nov. 2019.

JENSEN, John R. Sensoriamento remoto do ambiente: uma perspectiva em recursos terrestres. São Paulo: Parêntese, 2009. 
LOMBARDO, Magda Adelaide. Ilha de calor nas metrópoles, o exemplo de São Paulo. São Paulo: Hucitec, 1985.

MACHADO, Francisco Lisboa Vieira; JARDIM, Carlos Henrique. Indicadores climáticos de degradação ambiental em áreas urbanas: o aglomerado da Serra em Belo Horizonte/Brasil. In: SILVA, Charlei Aparecido da; FIALHO, Edson Soares; STEINKE, Ercília Torres T. (orgs.). Experimentos em climatologia geográfica. Dourados, MS: UFGD, 2014. p. 7 - 15.

MELO, Felippe Pessoa de. Risco ambiental e ordenamento do território em Garanhuns PE. Tese (Doutorado em Geografia) - Universidade Federal de Sergipe, São Cristovão, SE, 2016. Disponível em: https://ri.ufs.br/handle/riufs/5464/. Acesso em: 20 jun. 2020.

MENDONÇA, Francisco. O clima urbano de cidades de porte médio e pequeno: aspectos teórico-metodológicos e estudo de caso. In: SANT'ANNA NETO, João Lima; ZAVANTINI, João Afonso. Variabilidade e mudanças climáticas: implicações ambientais e socioeconômicas. Maringá, PR: Eduem, 2000. p. 167 - 192.

MONTEIRO, Carlos Augusto de Figueiredo; MARKUS, Eva; GOMES, Katharina Markhan Ferreira. Comparação da pluviosidade nos Estados de São Paulo e Rio Grande do Sul nos invernos de 1957 e 1963. São Paulo: IGEOG-USP, 1971. p. 01-05.

MORENO, Gislaene; HIGA, Tereza Cristina Souza. Dinâmica populacional de Mato Grosso. In: MORENO, Gislaene; HIGA, Tereza Cristina Souza (orgs.). Geografia de Mato Grosso: território, sociedade e ambiente. Cuiabá: Entrelinhas, 2005. p. 72 - 87.

NASA - National Aeronautics and Space Administration. Landsat 8 Thermal Infrared Sensor (TIRS) Update. 2014. Disponível em:

http://landsat.usgs.gov/about_LU_Vol_8_Issue_2.php\#2a. Acesso em: 04 set. 2018.

NIMER, Edmon. Geografia do Brasil. Região Centro-Oeste. Rio de Janeiro: IBGE, 1989. v. 1.

ROSS, Jurandir; VASCONCELOS, Tereza Neide Nunes; CASTRO JÚNIOR, Prudêncio Rodrigues de. Estrutura e formas de relevo. In: MORENO, Gislaene; HIGA, Tereza Cristina Souza (orgs.). Geografia de Mato Grosso: território, sociedade e ambiente. Cuiabá: Entrelinhas, 2005. p. $218-237$.

SETTE, Denise Maria; TARIFA, José Roberto. O holorítmo e a gênese dos climas no Mato Grosso - Brasil, In: SIMPÓSIO BRASILEIRO DE CLIMATOLOGIA GEOGRÁFICA, 4., Rio de Janeiro, RJ. Anais [...]. Rio de Janeiro: UFRJ, 2000. p. 23-38.

SIQUEIRA, Elizabeth Madureira. História de Mato Grosso: da ancestralidade aos dias atuais. Cuiabá: Entrelinhas, 2002.

STEINKE, Valdir Adilson; STEINKE, Ercília Torres. Correlação entre umidade relativa do ar e parâmetros fisiográficos da paisagem do parque urbano olhos da água-Brasília-DF. In: SILVA, Charlei Aparecido da; FIALHO, Edson Soares; STEINKE, Ercília Torres (orgs.).

Experimentos em climatologia geográfica. Dourados: UFGD, 2014. p. 187-199.

TARIFA, José Roberto; AZEVEDO Tarik Rezende de. Os climas naturais. GEOUSP: Espaço e Tempo, São Paulo, SP, n. 4, p. 47 - 70, 2001.

YNOUE, Rita Yuri et al. Meteorologia: noções básicas. São Paulo: Oficina de Textos, 2017.

Recebido: abril de 2020. Aceito: julho de 2020. 